\title{
Innovative Social Media Marketing Communication Application for Thai Hotel SMEs
}

\author{
https://doi.org/10.3991/ijim.v14i16.15199 \\ Torboon Puangmaha ${ }^{\bowtie}$, Tatri Taiphapoon, Pakpachong Vadhanasindhu, \\ Sukree Sinthupinyo \\ Chulalongkorn University, Bangkok, Thailand \\ Torboon.Pestudent.chula.ac.th
}

\begin{abstract}
Social media marketing communication has been widely adopted in organization due to its values of interactivity, integration of communication channels, information collection and immediacy. Nevertheless, a majority of small and medium enterprise (SMEs) do not realize how to systematically and effectively implement social media marketing communication. Few studies on application development of social media marketing communication, however, have demonstrated the support for Thai hotel SMEs. This study aims to understand the pain points and expectations of SMEs in the Thai hotel industry, to design and develop innovative social media marketing communication applications for business promotion. The research utilizes design thinking process for application development using semi-structured interviews with 10 industry professionals. Based on results from the data analysis and conceptual prototype design, validated by group of professionals in business, innovation design and technology, the proposed prototype is practical and suitable for developing an innovative application that promotes Thai hotel SMEs' social media marketing communication.
\end{abstract}

Keywords - Social media communication, social media marketing, Thai hotels, SMEs.

\section{Introduction}

The revolution in Internet and mobile technologies continues to alter the current social network technology. Today, searching for and sharing customers' stories is very easy and comfortable. Any individual having a smart device with Internet can access social networks anywhere, anytime [1]. In Thailand, the average amount of time people spend per day on social networks is 3 hours and 11 minutes, and 93\% of Internet users are on Facebook, 91\% on YouTube, followed by $65 \%$ on Instagram and 52\% on Twitter. In addition, Bangkok, the capital of Thailand, was ranked as having the highest number of Facebook users globally, with 22 million accounts [2].

Thus, the number of daily social media users has increased tremendously [3]. This phenomenon has resulted in new business opportunities for everyone. Social networks have become important communication channels because they have changed people's 
consumer behaviour [4] and provide a new way of communicating with customers and selling products and services. Additionally, social media technology allows corporations to communicate with customers, listen to comments and feedback, understand customers' attitude, and learn their needs instantly without any limitation of geography during communication [5].

In Thailand's hotel industry, the number of tourists have been growing at the rate of $15 \%$ per year and are expected to reach 41.5 million in 2020 [6]. The total Thai hotel business revenue was THB 566-574 billion in 2017, and it is growing by $3.7-5.5 \%$ year over year [7]. However, most Thai hotels, especially the small and medium-sized enterprises (SMEs) - find it difficult to manage the rooms to maximise their occupancy [8]. The challenges mainly involve acquiring new customers at an effective cost and maintaining good relationships with old customers so that they revisit or reengage with the hotels under the current situation of fast-changing consumer behaviours on the fragmented social media platforms.

To identify such problems in Thai hotels' social media marketing, this study interviewed 10 professionals from the Thai hotel industry. These interviews elicited various opinions on problems related to the hotels' focus during social media marketing, the major topics, and lack of the hotels' social media skills, as well as the lack of knowledge about the audience's behaviours and needs, content creation, social media indicators and search engine optimisation, and the objectives of social marketing communication [9].

Therefore, this study aims to understand the pain points and expectations of Thai hotels SMEs and develop a prototype of an innovative social marketing communication application for Thai hotel SMEs.

\section{$2 \quad$ Literature Review}

\subsection{Storytelling and social media}

Storytelling: The revolution of digital technologies has led people to use the Internet because it is accessible anywhere and anytime. The Internet provides content that can spread rapidly via websites and mobile applications. Therefore, storytelling has become a part of online media and social media marketing that help users connect with people around the world and share their opinions and feelings [5], [10].

As a social media marketing strategy, interesting storytelling has gained increasing attention as a way to attract travellers. Storytelling is related to word of mouth and voice of the customer, and a good story can help improve an organisation's image. Many organisations present their own stories or utilise stories related to customers' feedback/reviews as well as journey- and service-related stories. Therefore, storytelling is one of the most important factors in social media marketing strategies.

Social media: The phenomenal rise of digital technology and emergence of the Internet has changed the way users communicate. Many people spend more time communicating online than offline. The Internet allows users to create, share, talk, text, watch videos, write, entertain, and search for information online. These changes have 
led to the creation of social media channels such as Facebook, YouTube, Instagram, and Twitter. Social media channels are Internet-based applications that any user with a smart device having Internet access can use anywhere and anytime [11]. These channels allow users to create and share content and connect with other people by sharing ideas and experiences, meeting, blogging, and posting [12].

\subsection{Social media marketing strategies in Thailand's hotel industry}

Social media has been developed for decades, starting from websites and upgrading to multiplatform [13] owing to the revolution in communication technologies. These developments have allowed people to use social media-whose original objective was enabling human connection anywhere and anytime [14] - to remain connected online and share their profiles, photos, videos, comments, shares, and likes and send messages to keep in touch with friends, family, and colleagues.

The Global Digital Report 2019 [2] stated that in 2019, Facebook was one of the most popular social networking platforms in Thailand. The number of Thai people accessing advertising on Facebook was still 50 million people, followed by Instagram (13 million people), Twitter (4.7 million people), Snapchat (555,000 people), and LinkedIn (over 2.4 million people). Moreover, YouTube is the one of the most popular websites with Thai people [2].

Many people have tried to implement social media marketing strategies to increase the effectiveness of their communication in delivering and exchanging messages or to ensure content is valuable to parties related to the organisations. In the hotel industry, social media is changing the way hotel businesses communicate with their consumers [14], [15].

\subsection{Design thinking process}

Design thinking is one of the most efficient modelling processes for developing innovations through creativity. Creating an innovation must be a multidisciplinary process because ideas from the multidisciplinary members would help designers find effective ways to solve problems. A design thinking model involves the following steps [16]:

Empathise: In this step, researchers attempt to understand the problems as well as customers' requirements, motivation, and experience to determine ways to solve those problems.

Define: This step involves identifying and defining the problems by analysing all the data obtained from the 'empathise' step.

Ideate: This involves brainstorming by the multidisciplinary members for ideation.

Prototype: The prototype is developed for idea testing.

Test: The prototype's efficiency is evaluated through testing. 


\section{Research Framework and Methodology}

\subsection{Framework}

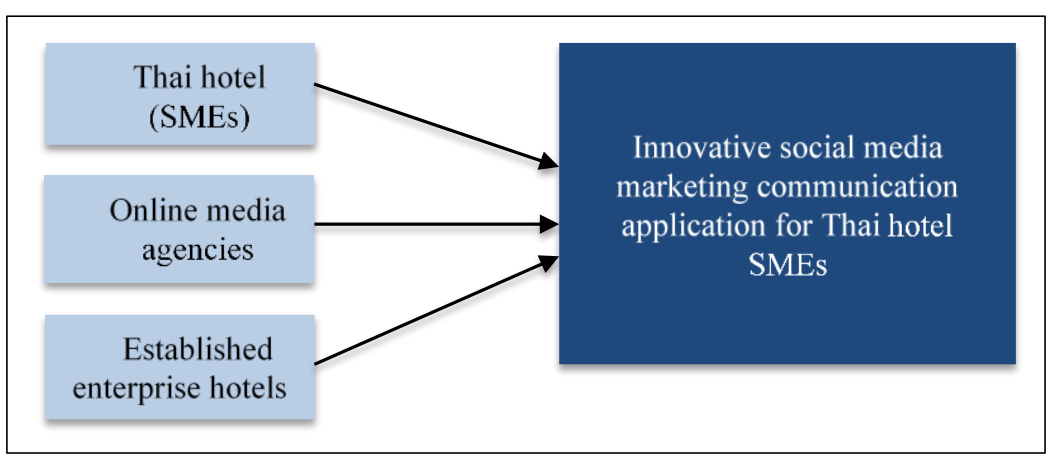

Fig. 1. Conceptual framework for the development of an innovative social media marketing communication application for Thai hotel small and medium-sized enterprises (SMEs)

Figure 1 presents the conceptual framework of this research and shows that the main target of this study is the Thai hotel (SME) industry and social media marketing communication. Additionally, the objective of this study is to develop an innovative social media marketing communication application for Thai hotel SMEs that can be measured by their need level. Another outcome is that this application can increase the opportunities for innovation development for the Thai hotel (SME) industry and its marketing teams. Thus, the stimulus for this research is finding an innovation gap for developing a suitable application for the Thai hotel (SME) industry and marketing team.

\subsection{Methodology}

This research used qualitative methods for collecting data. The process is divided into five steps.

Step 1: Semi-structure interview: We conduct semi-structured interviews using an interview questionnaire form with 10 professionals from the Thai hotel industry: five from SME hotel businesses who are experts in hotel management and traditional marketing, three from online media agencies who are experts in online marketing, and two from established enterprise hotel marketing teams. Seven interviews were conducted by face to face meetings while the other three interviews were arranged by phone because of remote locations throughout the country. They were chosen to identify answers to the questions listed in Tables 1 and 2.

Step 2: Data cleansing: We conduct data cleansing wherein we transcribe the data obtained from the 10 professionals. Then, we code and map the data. 
Step 3. Data modelling: We use an affinity diagram to organise the number of ideas and consolidate information related to the process of creating an application.

Step 4. Data analysis: We use thematic analysis to analyse the qualitative data and to identify thematic patterns in the interview data.

Step 5. Prototype development: We analyse the data to develop conceptual prototype design which were validated by various professionals including Thai hotel marketing experts, innovation designers and technology developers.

Table 1. Interview questions and goals for Thai hotel small and medium-sized enterprises

\begin{tabular}{|c|c|c|}
\hline No. & Question & Goal \\
\hline 1 & Do you use social media? & \multirow{2}{*}{$\begin{array}{l}\text { To learn about their familiarity with the } \\
\text { use of social media }\end{array}$} \\
\hline 2 & How often do you use social media? & \\
\hline 3 & $\begin{array}{l}\text { Do you think social media expertise has the potential of af- } \\
\text { fecting your social media marketing? }\end{array}$ & $\begin{array}{l}\text { To learn about the impact of social me- } \\
\text { dia expertise on social media marketing }\end{array}$ \\
\hline 4 & Do you conduct social media marketing in your hotel? & \multirow{2}{*}{$\begin{array}{l}\text { To know their perspective on the im- } \\
\text { portance of social media marketing. }\end{array}$} \\
\hline 5 & Who conducts social media marketing in your hotel? & \\
\hline 6 & In your opinion, what is social media marketing? & \multirow{5}{*}{$\begin{array}{l}\text { To understand their fundamental } \\
\text { knowledge about social media marketing } \\
\text { (base knowledge) }\end{array}$} \\
\hline 7 & $\begin{array}{l}\text { In your opinion, what are the objectives and goals of social } \\
\text { media marketing? }\end{array}$ & \\
\hline 8 & $\begin{array}{l}\text { In your opinion, what important things must be done in so- } \\
\text { cial media marketing? }\end{array}$ & \\
\hline 9 & How many types of social media marketing are there? & \\
\hline 10 & $\begin{array}{l}\text { What is your indicator for the success of social media } \\
\text { marketing? }\end{array}$ & \\
\hline 11 & $\begin{array}{l}\text { If your social media marketing does not work, how would } \\
\text { you solve this problem? }\end{array}$ & \multirow{2}{*}{$\begin{array}{l}\text { To understand their fundamental } \\
\text { knowledge about social media marketing } \\
\text { (process) }\end{array}$} \\
\hline 12 & $\begin{array}{l}\text { Do you have a process for planning and implementing social } \\
\text { media marketing? }\end{array}$ & \\
\hline 13 & $\begin{array}{l}\text { What problems and obstacles do you face in your social me- } \\
\text { dia marketing? }\end{array}$ & \multirow[t]{2}{*}{$\begin{array}{l}\text { To identify the problems in social media } \\
\text { marketing }\end{array}$} \\
\hline 14 & $\begin{array}{l}\text { If you are unable to conduct social media marketing your- } \\
\text { self, how do you solve this problem? }\end{array}$ & \\
\hline 15 & $\begin{array}{l}\text { What factors do you think will make your social media mar- } \\
\text { keting effective? }\end{array}$ & $\begin{array}{l}\text { To know about their expectation with us- } \\
\text { ing social media marketing }\end{array}$ \\
\hline
\end{tabular}


Table 2. Interview questions and goals for established enterprises' hotel marketing teams and online media agencies

\begin{tabular}{|c|c|c|}
\hline No. & Question & Goal \\
\hline 1 & In your opinion, what is social media marketing? & \multirow{10}{*}{$\begin{array}{l}\text { To learn about the work processes of the mar- } \\
\text { keting team and agencies }\end{array}$} \\
\hline 2 & $\begin{array}{l}\text { In your opinion, what are the objectives and goals of } \\
\text { conducting social media marketing? }\end{array}$ & \\
\hline 3 & $\begin{array}{l}\text { In your opinion, what important things must be done } \\
\text { in social media marketing? }\end{array}$ & \\
\hline 4 & How many types of social media marketing are there? & \\
\hline 5 & $\begin{array}{l}\text { What is your indicator for the success of social media } \\
\text { marketing? }\end{array}$ & \\
\hline 6 & $\begin{array}{l}\text { If your social media marketing does not work, how } \\
\text { can you solve this problem? }\end{array}$ & \\
\hline 7 & $\begin{array}{l}\text { Do you have a process for planning and implementing } \\
\text { social media marketing? }\end{array}$ & \\
\hline 8 & $\begin{array}{l}\text { What are the problems and obstacles in your social } \\
\text { media marketing? }\end{array}$ & \\
\hline 9 & $\begin{array}{l}\text { Does your hotel have a framework (canvas) for con- } \\
\text { ducting social media marketing? }\end{array}$ & \\
\hline 10 & $\begin{array}{l}\text { How do you present your social media marketing plan } \\
\text { to customers? }\end{array}$ & \\
\hline 11 & $\begin{array}{l}\text { If you have to conduct social media marketing for } \\
\text { your hotel, what is the process? }\end{array}$ & $\begin{array}{l}\text { To know about the conceptual thinking of the } \\
\text { marketing team and agencies }\end{array}$ \\
\hline 12 & $\begin{array}{l}\text { What software do you use for your social media mar- } \\
\text { keting? }\end{array}$ & $\begin{array}{l}\text { To learn about the work process of the market- } \\
\text { ing team and agencies }\end{array}$ \\
\hline 13 & $\begin{array}{l}\text { What do you think are the key factors that make so- } \\
\text { cial media marketing successful? }\end{array}$ & $\begin{array}{l}\text { To know about the conceptual thinking of the } \\
\text { marketing team and agencies }\end{array}$ \\
\hline 14 & $\begin{array}{l}\text { What obstacles do you face in working with custom- } \\
\text { ers or leaders? }\end{array}$ & $\begin{array}{l}\text { To identify the obstacles the marketing team } \\
\text { and agencies face in the work process }\end{array}$ \\
\hline 15 & $\begin{array}{l}\text { What do you think about doing social media market- } \\
\text { ing in a team? }\end{array}$ & $\begin{array}{l}\text { To identify the problems in hotels' social media } \\
\text { marketing }\end{array}$ \\
\hline
\end{tabular}

\section{$4 \quad$ Results}

Step 1: Semi-structured interview: Based on the interview results, various opinions were obtained on focus-related pain points. Researchers received raw data for transcription and coding in the next step.

Step 2: Data cleansing: In data cleansing, the transcribe technique was used to convert audio to text. This text was coded to highlight significant messages, which were then written down on Post-it notes. The results of this step are shown in Figures 2-4. 
Paper-Innovative Social Media Marketing Communication Application for Thai Hotel SMEs

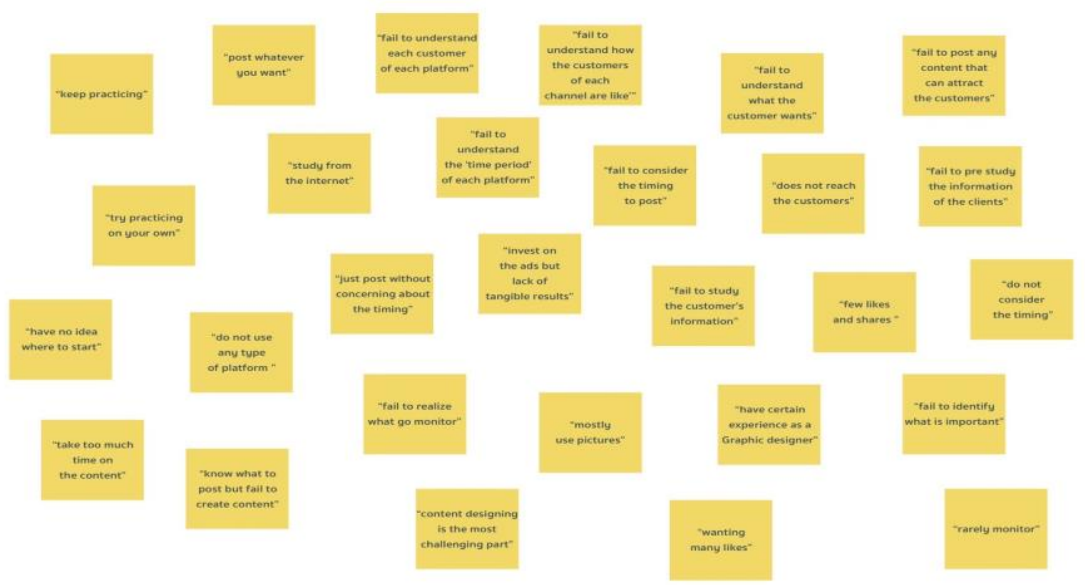

Fig. 2. Result of data cleansing after transcription and coding: pain points of Thai hotel small and medium-sized enterprises (SMEs)

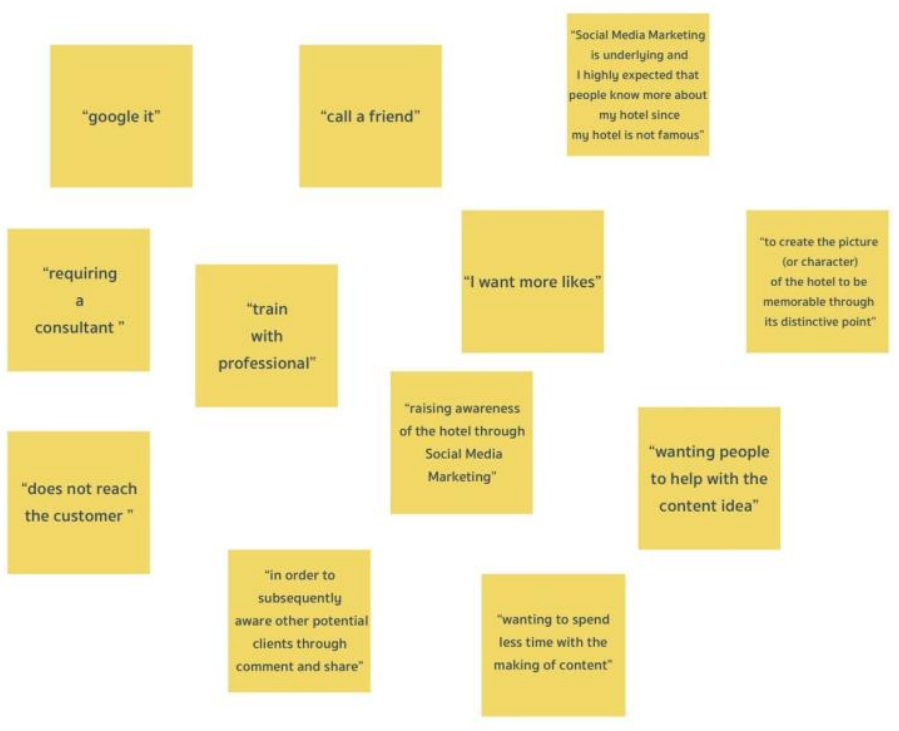

Fig. 3. Result of data cleansing after transcription and coding: expectations of Thai hotel small and medium-sized enterprises (SMEs) 


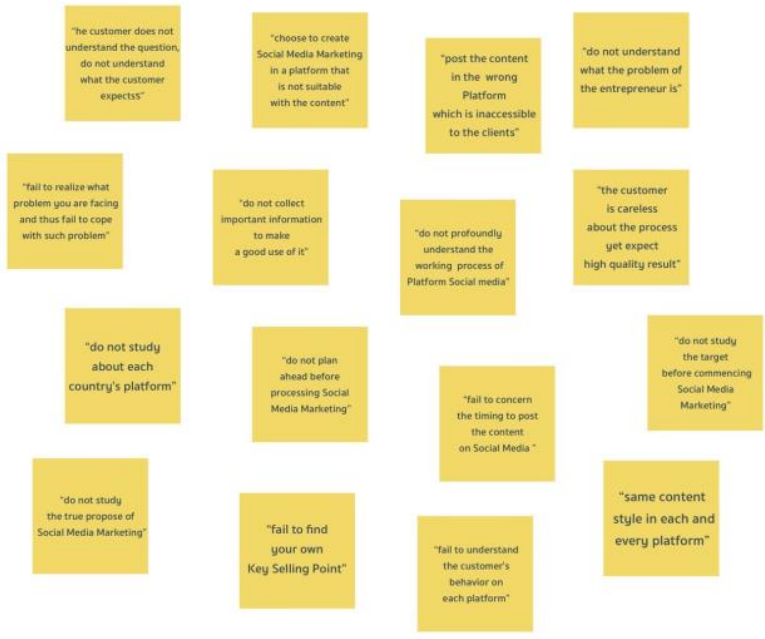

Fig. 4. Result of data cleansing after transcription and coding: perspectives of agencies regarding Thai hotel small and medium-sized enterprises (SMEs)

Step 3: Data modelling: In data modelling, the affinity diagram was used as a tool for classifying and grouping data after cleansing. The results of this step are shown in Figures 5-7.
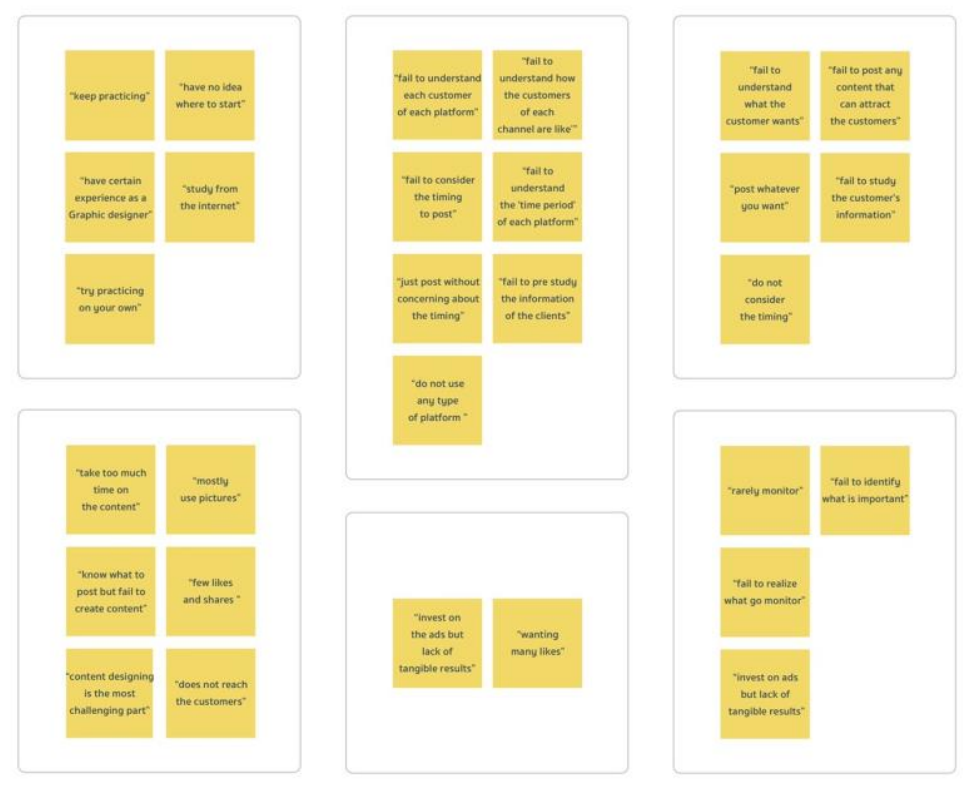

Fig. 5. Result of data modelling with an affinity diagram: pain points of Thai hotel small and medium-sized enterprises (SMEs) 

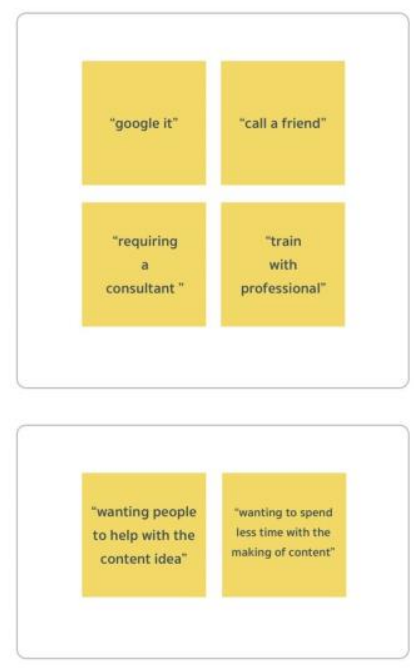

Fig. 6. Result of data modelling with an affinity diagram: expectations of Thai hotel small and medium-sized enterprises (SMEs)
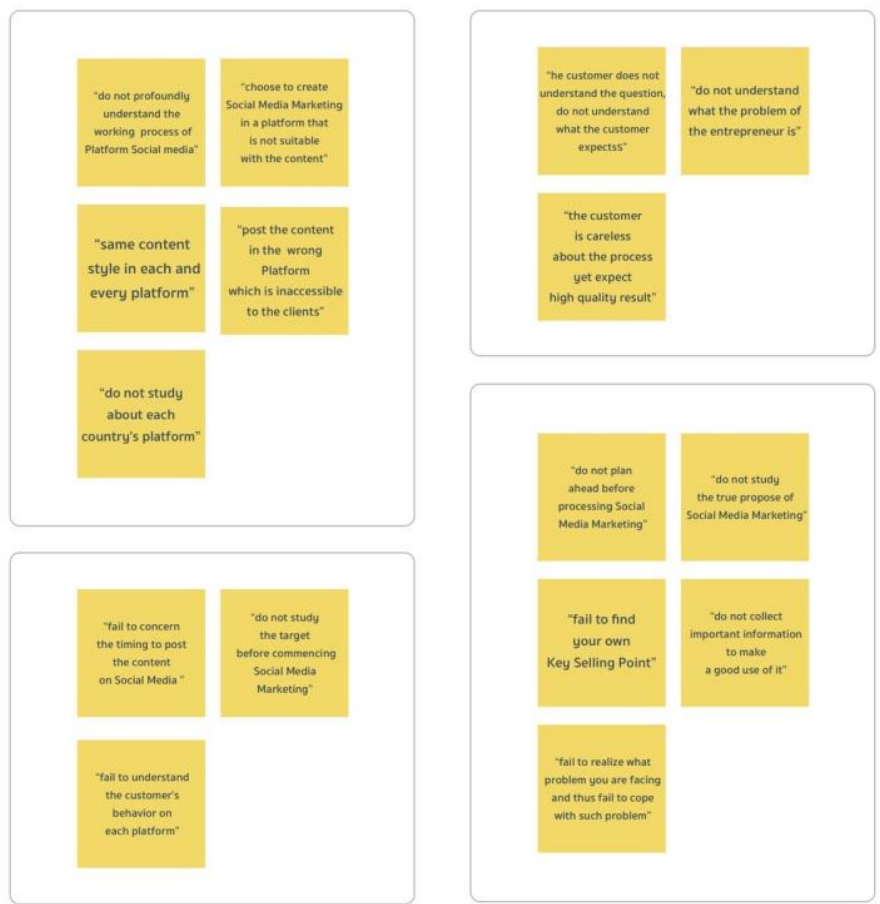

Fig. 7. Result of data modelling with an affinity diagram: perspectives of agencies regarding Thai hotel small and medium-sized enterprises (SMEs) 
Step 4: Data analysis: In this step, thematic analysis was used as a tool to analyse data and map users' need for prototype development. The data analysis is described below and illustrated in Figures 8-10.

Pain points: The pain points of Thai hotel SMEs are summarised into the following topics:

- Topic 1: Lack of expertise

- Topic 2: Unknown behaviour using social media marketing for target groups

- Topic 3: Unknown demand of the target groups

- Topic 4: No idea for developing content

- Topic 5: Unknown indicators for conducting social media marketing

- Topic 6: Unknown purpose of conducting social media marketing

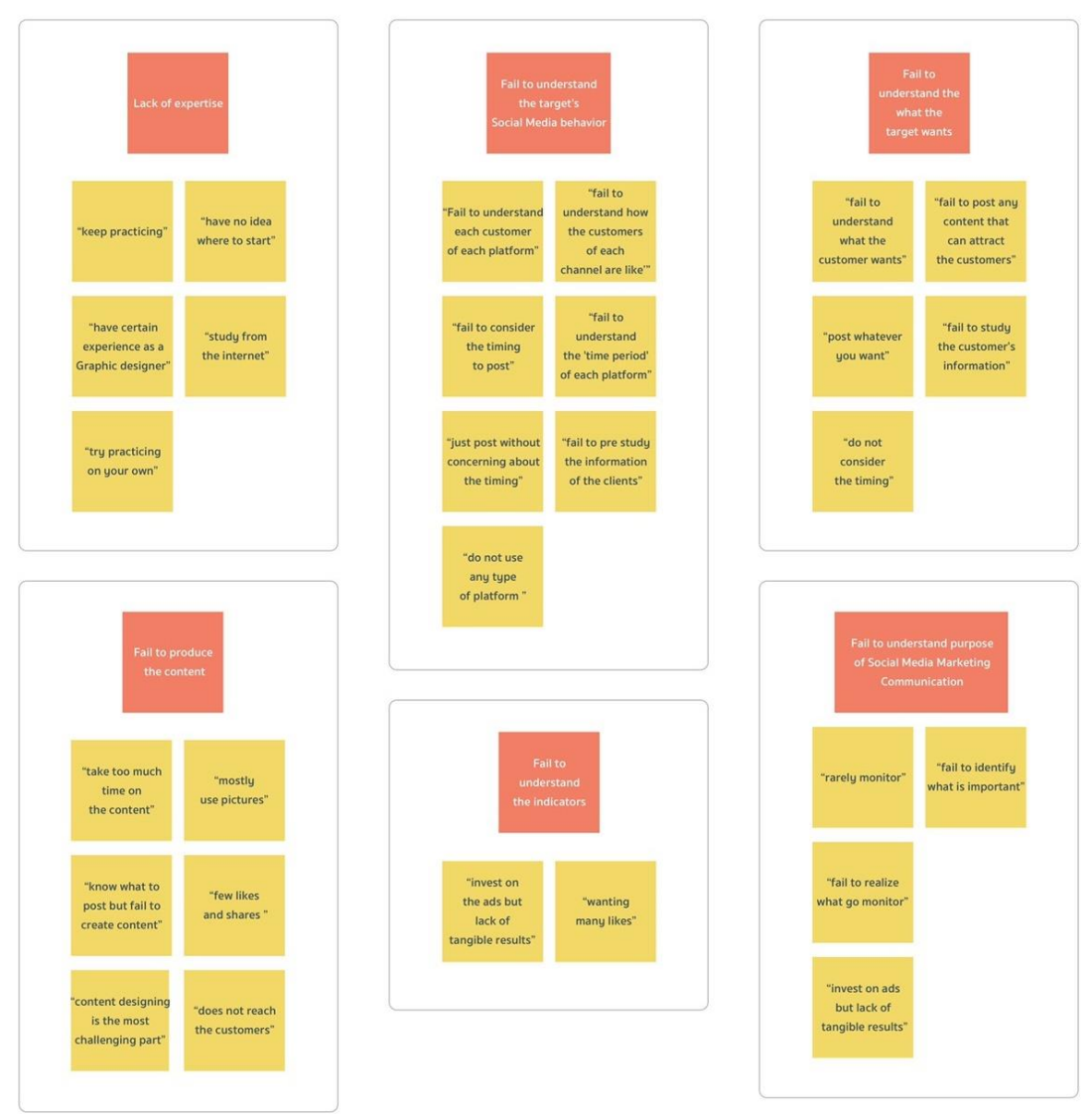

Fig. 8. Result of data analysis using thematic analysis: pain points of Thai hotel small and medium-sized enterprises (SMEs) 
Expectation: The expectations of Thai hotel SMEs are summarised into the following topics:

- Topic 1: Find a consultant

- Topic 2: Create awareness, engagement, and value

- Topic 3: Generate ideas for creating content

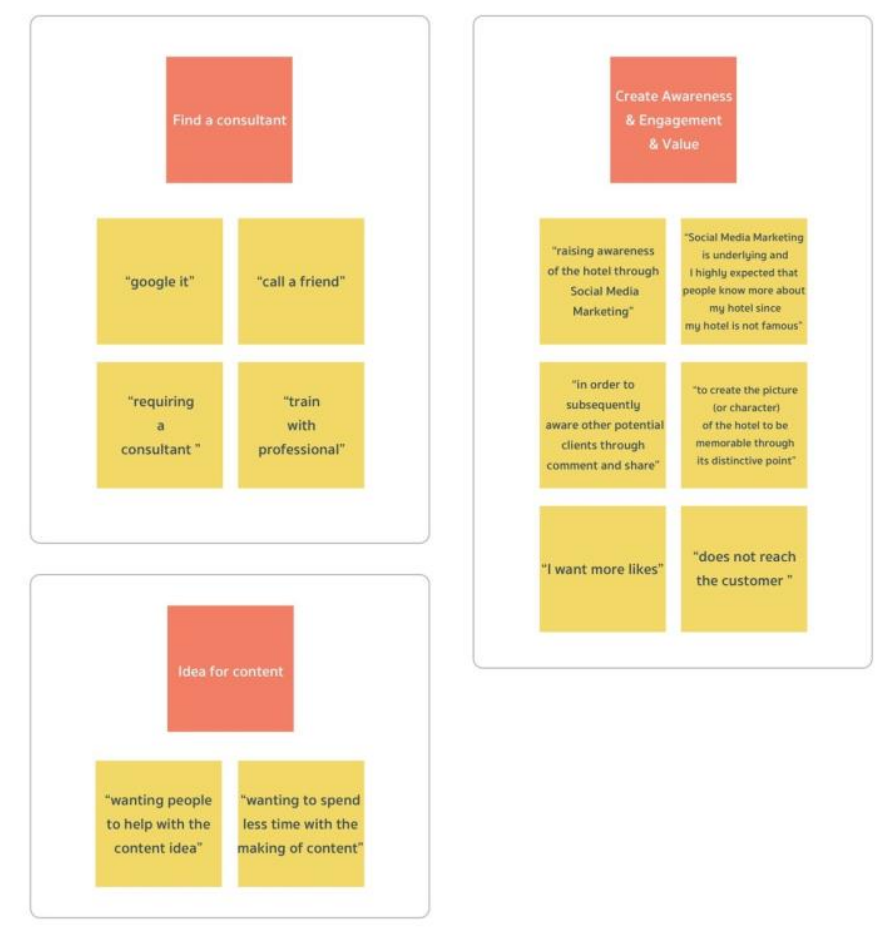

Fig. 9. Result of data analysis using thematic analysis: expectations of Thai hotel small and medium-sized enterprises (SMEs)

Perspectives: The perspectives of the professional marketing team about Thai hotel SMEs are summarised into the following topics:

- Topic 1: Do not understand goal and expect more

- Topic 2: Do not understand the consumer in each platform

- Topic 3: Do not understand the consumer need

- Topic 4: Lack of content planning and strategy 

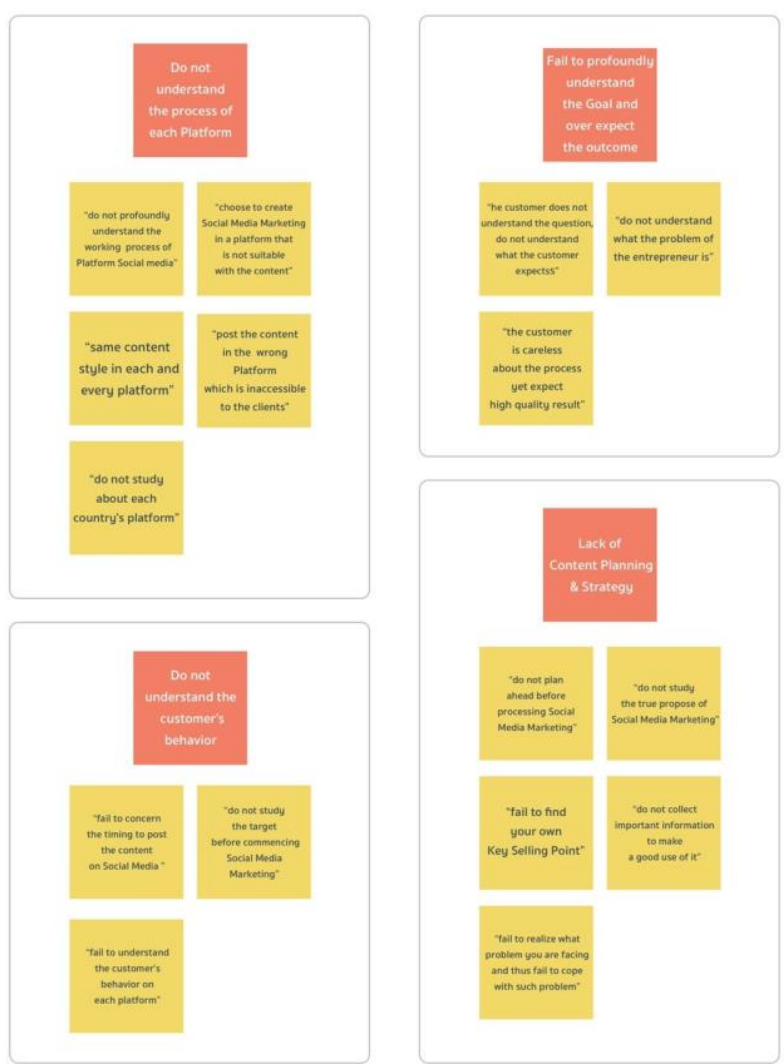

Fig. 10.Result of data analysis using thematic analysis: perspectives of agencies regarding Thai hotel small and medium-sized enterprises (SMEs)

Step 5: Prototype development: As part of the design and development of this prototype, various functions are suggested, such as content types, suggested social media channels, suggested words, and content setup for creating a new post. Details of these functions are presented in Table 4, which shows some of the main screens of the prototype. 
Table 3. Description of the innovative social media marketing communication application prototype for Thai hotel small and medium-sized enterprises (SMEs)

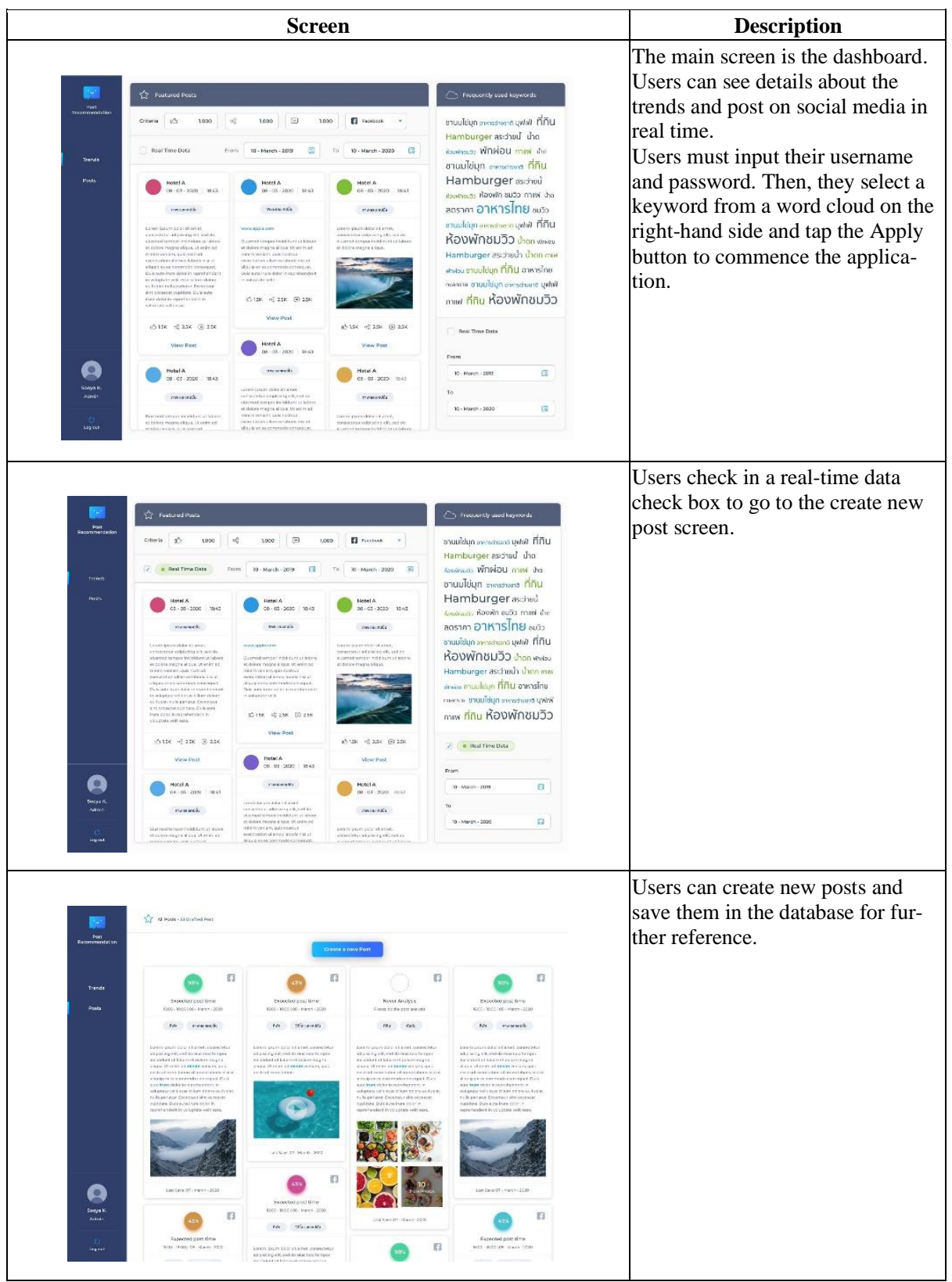


Paper-Innovative Social Media Marketing Communication Application for Thai Hotel SMEs

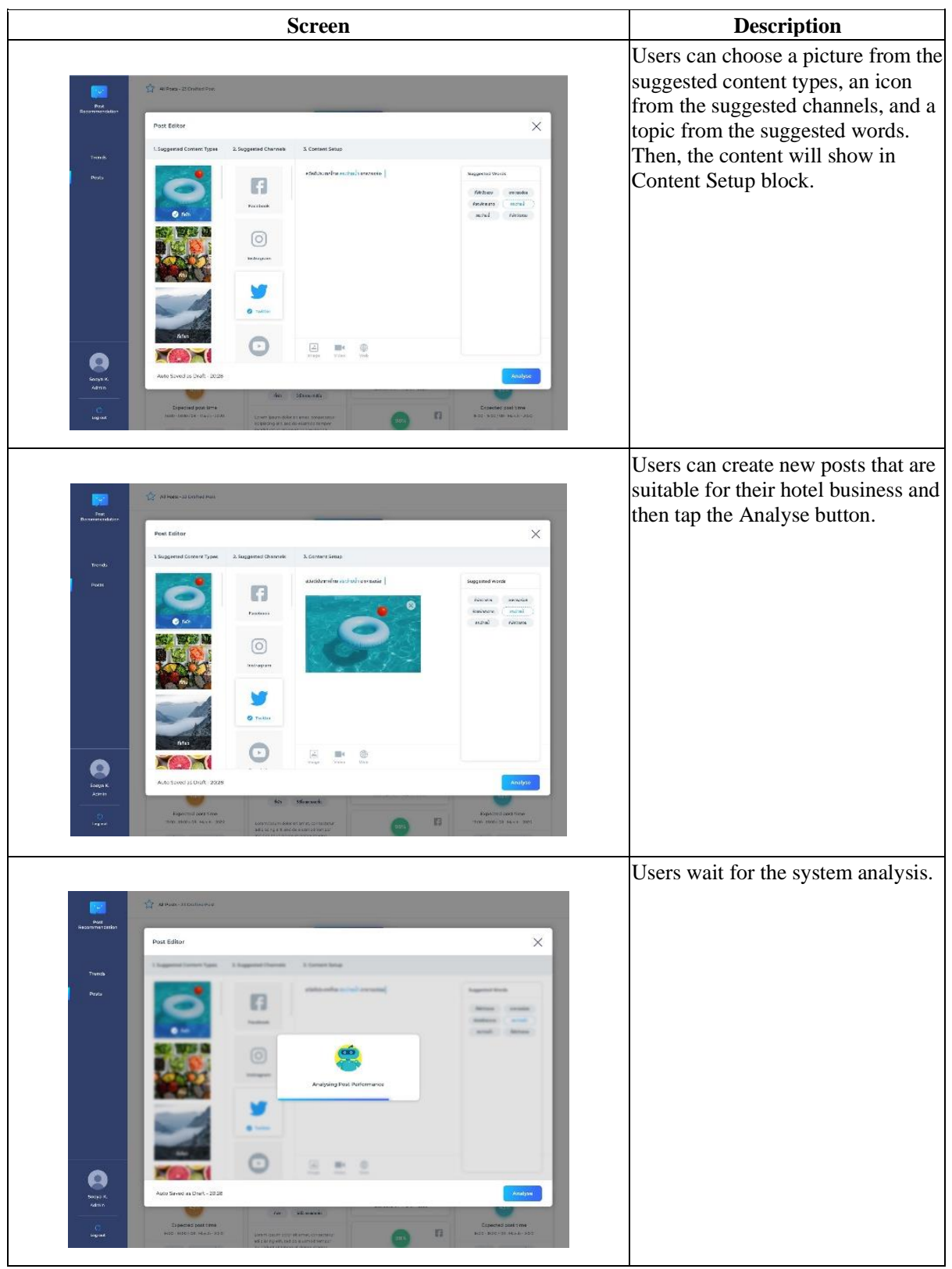




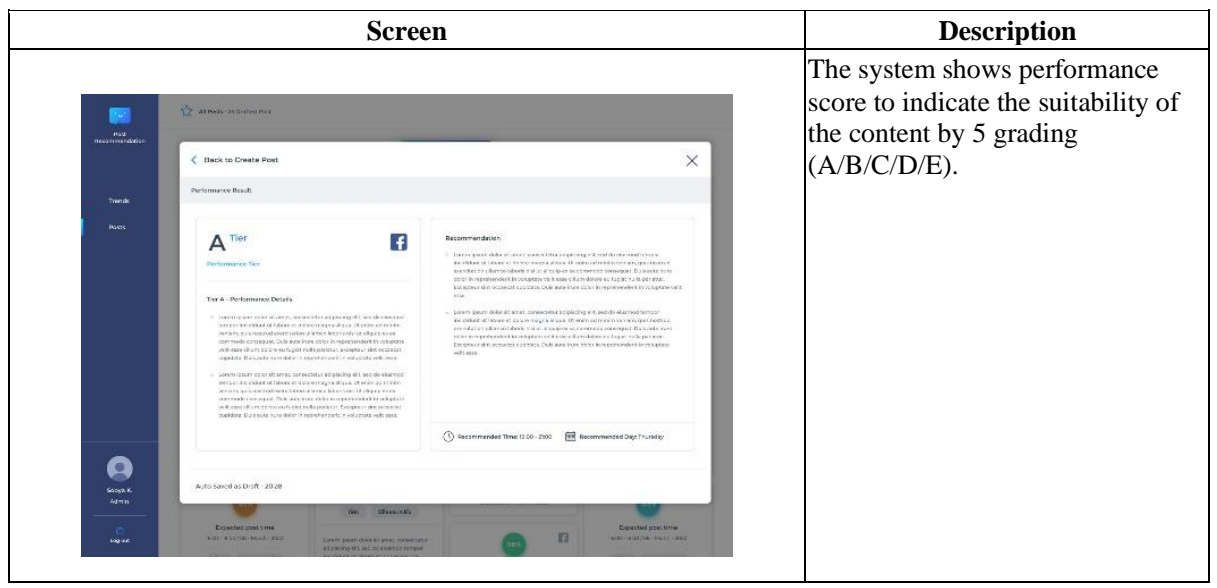

Table 4 shows the flow and relationships between the interaction design process and the prototype for the innovative social media marketing communication application for Thai hotel SMEs. Figure 11 further illustrates these relationships.

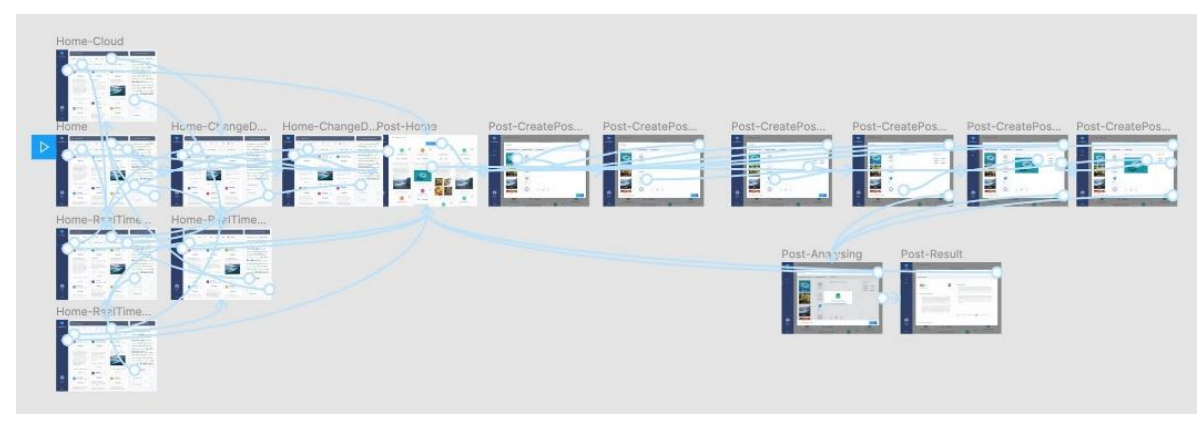

Fig. 11.Relationships among interaction design and prototype in Table 2.

After data collection and processing, the analysis results indicate that in this research has created a new opportunity for innovation development, which were mainly driven from understanding Thai hotel SMEs' pain points and their expectations as well as professional marketing teams' perspectives regarding Thai hotel SMEs.

The proposed prototype was developed and validated by group of professionals in three specific areas of business, innovation design and technology. Therefore, the innovative social media marketing communication application prototype for Thai hotel SMEs can be considered an effective tool and help these SMEs create new suitable posts for their businesses.

\section{Conclusion and Discussion}

According to the literature, not all channels and types of social media are suitable for each hotel marketing context. While one may help post on some social media 
channels several times a day, others may be useful for reaching only special groups of customers. Thus, this research aimed to develop a prototype of an innovative social media marketing communication application to promote Thai hotel SMEs' businesses by providing them new opportunities for innovation development. To achieve this, the researchers used the interaction design process method.

The target sample group included 10 professionals from the Thai hotel industry. As a research outcome, this study created a new opportunity for innovation development for these businesses. This prototype was validated by group of various professionals as being practical and suitable for developing an innovative social media marketing communication application to promote Thai hotel SMEs' social media marketing.

Moreover, this research identified that the relationships among the prototype and its interaction design and prototype were obvious and consistent. Therefore, the proposed model can support Thai hotel SMEs' social media marketing.

The prototype was developed as an innovative social media communication model for Thai hotel SMEs and would be practical to apply for other related travel services, for example, restaurants, spas, etc.

This research is limited by using some phone interviews for data collection of samples locating in remote areas throughout Thailand. While face to face interviews allow better engagement, phone interviews permit convenience and accessibility for data collection anywhere in the country.

In future research, we would like to enhance a quantifying survey to validate indepth data analysed from our studied qualitative research. Both in-depth and quantifiable data collection and analysis would improve the proposed prototype. In addition, we would also like to conduct an acceptance testing research with Thai hotel SMEs to complete new application development.

\section{References}

[1] P. P. Correia, and I. G. Medina, "Digital social media: An interactive technology incorporated as a competitive advantage for business," International Journal of Interactive Mobile Technologies, vol. 8, no. 2, 23-27, 2014. https://doi.org/10.3991/ijim.v8i2.3576

[2] Hootsuite, "Global digital 2019 reports," Hootsuite, 2019. [Online] Available: https://hootsuite.com.

[3] G. Blank, and C. Lutz, "The social structuration of six major social media platforms in the United Kingdom: Facebook, LinkedIn, Twitter, Instagram, Google+ and Pinterest," In Proc. 7th 2016 International Conference on Social Media \& Society, July 2016, pp. 1-10. https://doi.org/10.1145/2930971.2930979

[4] A. Infante-Moro, J. C. Infante-Moro, F. J. Martínez-López, and M. García-Ordaz, "The importance of Internet and online social networks in the Spanish hotel sector," Applied Computer Science, vol. 12, no. 1, pp. 75-86, 2016.

[5] R. Pera, "Empowering the new traveller: Storytelling as a co-creative behaviour in tourism," Current Issues in Tourism, vol. 20, no. 4, 331-338, 2017. https://doi.org/10.1080 $\underline{13683500.2014 .982520}$ 
[6] Puttachard Lunkam, "Thailand industry outlook 2018-20: Hotel industry," Krungsri Research Center, December 2017. [Online]. Available: https://www.krungsri.com/bank/getmedia/5de62d20-1706-48c1-9573-65359fdbc76c/IO_Hotel_2017_EN.aspx

[7] Kasikorn Research Center, "Industry outlook analysis," Kasikorn Research Center, 2019. [Online]. Available: https://www.kasikornresearch.com/en/analysis/k-econ/business/Pages/36168.aspx

[8] A. Lowe, "Small hotel survival-An inductive approach," International Journal of Hospitality Management, vol. 7, no. 3, pp. 197-223, 1988. https://doi.org/10.1016/0278$\underline{4319(88) 90021-7}$

[9] M. C. Tom Dieck, T. H. Jung, W. G. Kim, and Y. Moon, "Hotel guests' social media acceptance in luxury hotels," International Journal of Contemporary Hospitality Management, vol. 29, no. 1, pp. 530-550, 2017. https://doi.org/10.1108/IJCHM-10-2015-0552

[10] Z. F. G. Romo, I. García-Medina, and N. P. Romero, "Storytelling and social networking as tools for digital and mobile marketing of luxury fashion brands," International Journal of Interactive Mobile Technologies, vol. 11, no. 6, pp. 136-149, 2017. https://doi.org/10.3991 /ijim.v11i6.7511

[11] A. M. Kaplan and M. Haenlein, "Users of the world, unite! The challenges and opportunities of social media," Business Horizons, vol. 53, no. 1, pp. 59-68, 2010. https://doi.org/10.1016 /j.bushor.2009.09.003

[12] U. Stankov, L. Lazic, and V. Dragicevic, "The extent of use of basic Facebook user-generated content by the national tourism organizations in Europe," European Journal of Tourism Research, vol. 3, no. 2, pp. 105-113, 2010.

[13] S. Rautela and A. Sharma, "Spirituality and social media: Connecting the dots," International Journal of Interactive Mobile Technologies, vol. 13, no. 09, pp. 81-98, 2019. https://doi.org/10.3991/ijim.v13i09.8863

[14] S. Vinerean, "Importance of strategic social media marketing," Expert Journal of Marketing, vol. 5, no. 1, pp. 28-35, 2017.

[15] C. Ristova and T. Angelkova, "How are social media influencers changing the hotel industry. Can your hotel benefit from it?" presented at the 18th International Scientific Conference - Contemporary Trends in Tourism and Hospitality "Get ready for iGeneration," Novi Sad, Serbia, Sept. 13, 2019.

[16] P. Gestwicki and B. McNely, "A case study of a five-step design thinking process in educational museum game design. Proceedings of Meaningful Play, 2012. [Online]. Available: https://pdfs.semanticscholar.org/868d/5c08904213b44e0b52af9117e7e27f2d2c1b.pdf

[17] J. Preece and Y. Rogers, Interaction Design: Beyond Human-Computer Interaction (5th ed.). Chichester, UK: Wiley, 2019.

\section{$7 \quad$ Authors}

Torboon Puangmaha is currently a Ph.D. student in the Technopreneurship and Innovation Management Program, Graduate School, Chulalongkorn University, Bangkok 10330, Thailand. E-mail: torboon.p@student.chula.ac.th 
Tatri Taiphapoon is currently an Associate Professor in the Department of Public Relation, Faculty of Communication Arts, Chulalongkorn University, Bangkok 10330, Thailand. E-mail: tatri.t@ chula.ac.th

Pakpachong Vadhanasindhu is currently an Associate Professor in the Technopreneurship and Innovation Management Program, Graduate School, Chulalongkorn University, Bangkok 10330, Thailand. E-mail: pak.v@acc.chula.ac.th

Sukree Sinthupinyo is currently an Assistant Professor in the Department of Computer Engineering, Faculty of Engineering, Chulalongkorn University, Bangkok 10330, Thailand. E-mail: sukree.s@chula.ac.th

Article submitted 2020-04-25. Resubmitted 2020-05-23. Final acceptance 2020-05-24. Final version published as submitted by the authors. 